\title{
RESISTENSI PENGGUNA TERHADAP SISTEM INFORMASI AKADEMIK UNIVERSITAS PGRI ADI BUANA SURABAYA
}

\author{
Susilo Hadi ${ }^{1}$, Lydia Lia Prayitno ${ }^{2}$ \\ ${ }^{1,2}$ Fakultas Keguruan dan Ilmu Pendidikan, Universitas PGRI Adi Buana Surabaya \\ email : susilohadi45@gmail.com ${ }^{1}$, lydia.liaprayitno5@gmail.com²
}

\begin{abstract}
Abstrak
Penerapan manajemen sistem informasi akademik berbasis teknologi informasi mutlak diperlukan oleh lembaga pendidikan, termasuk diantaranya adalah Universitas PGRI Adi Buana Surabaya. Sebagai konsekuensi dari aplikasi sistem informasi akademik tersebut, diperlukan penyediaan sarana dan dalam penggunaannya memerlukan keterlibatan berbagai pihak, antara lain mahasiswa, dosen dan staf di bagian operasional administrasi akademik. Sebagai hal yang baru, penerapan SIAKAD ini memerlukan adaptasi bagi masing-masing yang terlibat di dalam penerapannya. Ada resistansi pengguna sistem/user resistance, khususnya pada tingkat perilaku. Peneliti ingin mengidentifikasi resistansi dalam penggunaan sistem informasi akademik. Penelitian ini menggunakan pendekatan cross-sectional study. Populasi dalam penelitian ini adalah dosen, staf BAAK dan mahasiswa Program Studi Pendidikan Matematika. Jumlah sampel 100 orang yang diambil secara proporsional (proportionated sampling technique). Variabel dalam penelitian ini ada 4 variabel terkait dengan resistensi penggunaan sistem, yaitu :lack of user education and training (LUET), change in job content (CJC), lack of user involvement in the development process (LUID), and lack of communication between top management and enduser (LCMU). Data dikumpulkan dengan kuesioner, dan dianalisis secara deskriptif.
\end{abstract}

Kata Kunci: Information systems, user resistance

\section{A. PENDAHULUAN}

Pada era informasi seperti sekarang ini, teknologi informasi sangat dibutuhkan untuk mencapai efisiensi dan efektifitas organisasi (Wijaya, 2006), maka implementasi sistem manajemen (SIM) berbasis teknologi mutlak diperlukan bagi organisasi, tidak terkecuali institusi pendidikan. Sebagai sebuah organisasi penyelenggara pendidkan, Universitas PGRI Adi Buana Surabaya telah mengimplementasikan Sistem Informasi Akademik (SIAKAD), suatu SIM pendidikan yang bersifat web-based sejak tahun akademik 2014/2015. Sistem informasi tersebut sudah berjalan, namun masih ditemukan beberapa kendala terutama yang berkaitan dengan "user resistance" (penolakan pengguna). Berdasarkan hasil studi pendahuluan melalui observasi terhadap perilaku pengguna dalam penerapan SIAKAD di Fakultas Keguruan dan Ilmu Pendidikan, ditemukan adanya keengganan para pengguna dalam melaksanakan SIAKAD, bahkan ada user yang belum menerapkan SIAKAD sama sekali. Jika dirujuk pada klasifikasi resistansi terhadap perubahan menurut Cerom \& Cregor (2010), kondisi di atas masih berada dalam kategori ringan yaitu pada level perilaku apatis dan resistansi pasif. Sementara itu klasifikasi yang lebih berat yakni resistansi aktif dan resistansi agresif tidak ditemukan di lapangan. Meskipun tidak ada tanda-tanda resistansi dalam kategori berat, kondisi ini tidak boleh dibiarkan, karena pada dasarnya resistansi dapat menghambat terjadinya perubahan menuju kepada kondisi yang lebih baik. Studi pendahuluan melalui indepth interview dengan sepuluh orang pengguna SIAKAD menghasilkan tiga kemungkinan penyebab resistansi yaitu: 1) perubahan isi pekerjaan secara drastis dari off-line menuju on-line telah menjadi beban bagi pengguna, 2) pengguna harus mengorbankan banyak waktu dan tenaga untuk menguasai sistem tersebut, 3) struktur dan fungsi SIAKAD yang belum memenuhi harapan pengguna. Ini menunjukan terjadinya resistansi ringan terhadap implementasi SIAKAD. Hal inilah yang melatarbelakangi peneliti untuk melakukan penelitian mengenai resistansi pengguna dalam implementasi Sistem Informasi Akademik (SIAKAD) di Universitas PGRI Adi Buana Surabaya.

\section{B. RUMUSAN MASALAH}

Berdasarkan masalah yang diuraikan pada latar belakang maka disusun rumusan masalah yaitu: Faktor-faktor apa saja yang mempengaruhi resistansi pengguna dalam implementasi Sistem Informasi Akademik di Universitas PGRI Adi Buana Surabaya.

\section{METODE PENELITIAN}

Metode yang digunakan adalah rancangan penelitian deskriptif dengan pendekatan cross 
sectional. Rencana penelitian dilaksanakan pada bulan Mei - November 2016. Populasi dalam penelitian ini adalah dosen, karyawan, dan mahasiswa Universitas PGRI Adi Buana Surabaya yang memiliki kewajiban menggunakan SIAKAD pada Tahun Akademik 2014/2015. Besar sampel adalah 100 orang, yang diambil dengan teknik proportionated sampling. Data dikumpulkan menggunakan kuisioner tentang resistansi terhadap implementasi dalam sistem informasi yang berbasis teknologi dan determinannya diadopsi dari Salih, et al (2010), berupa skala likert dengan 5 opsi jawaban. Selanjutnya data dianalisis, secara deskriptif berupa tabel distribusi frekuensi dan persentase.

\section{HASIL PENELITIAN DAN PEMBAHASAN}

Penelitian telah dilakukan di Universitas PGRI Adi Buana Surabaya yang merupakan perguruan tinggi swasta dibawah PPLP PT PGRI Surabaya ( Perkumpulan Pembina Lembaga Pendidikan Perguruan Tinggi Persatuan Guru Republik Indonesia Surabaya, memiliki 5 (lima) fakultas dan 20 program studi. Responden berjumlah 100 orang yang terdiri dari 85 orang mahasiswa dan 15 orang dosen dan karyawan. Responden mahasiswa dan dosen, karyawan diambil secara acak yang mewakili program studi yang ada di Universitas PGRI Adi Buana Surabaya.

Jawaban responden didapat dari besarnya interval kelas mean setelah diketahui, kemudian dibuat rentang skala, sehingga dapat diketahui di mana letak rata-rata penilaian responden terhadap setiap variabel yang dipertanyakan. Contoh rentang skala mean tersebut ditunjukkan sebagai berikut :

$$
\text { Interval kelas }=\frac{\text { Nilai Tertinggi }- \text { Nilai Terendah }}{\text { Jumlah Kelas }}=\frac{5-1}{5}=0,8
$$

Hasil interval kelas 0,8 , maka dapat disimpulkan kriteria rata-rata jawaban responden adalah :

$$
\begin{aligned}
& 1,00-<1,80=\text { Sangat Tidak Setuju } \\
& 1,80-<2,60=\text { Tidak Setuju } \\
& 2,60-<3,40=\text { Biasa saja } \\
& 3,40-<4.20=\text { Setuju } \\
& 4,20-<5,00=\text { Sangat Setuju }
\end{aligned}
$$

Skala mean diatas untuk memberikan penilaian dalam menjawab pernyataan - pernyataan yang ada pada kuesioner.

Sebagaimana dijelaskan dalam definisi operasional variabel dalam penelitian ini antara lainLack Of UserEducation \& Training(LUET), Change In JobContent (CJC), Lack OfCommunicationBetween TopManagement \&End user (LCMU), Lack Of User OfInvolvement InThe DevelopmentProcess (LUID), Usability Issues \& Resistance ToTechnology (UIRT), IncreasedEffort
(IE), UserEspectation (UE), ResistanceDue To Change (RDC).

\section{- Analisis Deskriptif Variabel Lack of UserEducation \& Training (LUET)}

Sebagaimana dijelaskan dalam definisi Lack Of UserEducation \&Training(LUET) yang merupakan salah satu variabel bebas dengan 3 pernyataan yang ditunjukkan pada Tabel di bawah ini

Tabel 1. Hasil Pernyataan Responden Terhadap Variabel Lack Of UserEducation \& Training(LUET)

\begin{tabular}{|l|l|l|l|l|l|l|}
\hline No & \multicolumn{1}{|c|}{ Pernyataan } & \multicolumn{1}{|c|}{ STS } & \multicolumn{1}{|c|}{ TS } & \multicolumn{1}{|c|}{ BS } & SS \\
\hline 1 & $\begin{array}{l}\text { User memerlukan training dalam penggunaan } \\
\text { SIAKAD berbasis WEB online }\end{array}$ & - & 18 & 20 & 45 & 17 \\
\hline 2 & $\begin{array}{l}\text { User mendapatkan informasi mengenai petunjuk } \\
\text { penggunaan sebelum mengakses SIAKAD berbasis } \\
\text { WEB online }\end{array}$ & - & 6 & 22 & 53 & 19 \\
\hline 3 & $\begin{array}{l}\text { User mendapatkan sosialisasi mengenai manfaat dan } \\
\text { cara penggunaan dari SIAKAD berbasis WEB online }\end{array}$ & - & 12 & 24 & 53 & 11 \\
\hline & $\begin{array}{l}\text { Jumlah (\%) variable Lack of User Education\& } \\
\text { Training(LUET) }\end{array}$ & $\begin{array}{l}0 \\
(0 \%)\end{array}$ & $\begin{array}{l}36 \\
(12 \%)\end{array}$ & $\begin{array}{l}15 \%) \\
(50 \%)\end{array}$ & $\begin{array}{l}47 \\
(16 \%)\end{array}$ \\
\hline
\end{tabular}

Berdasarkan data pada tabel di atas didapatkan bahwa $50 \%$ responden menyatakan setuju perlu pelatihan tentang penggunaan SIAKAD berbasis
WEB Online, responden sudah mendapatkan informasi dan sosialisasi tentang penggunaan SIAKAD berbasis WEB Online.

Tabel 2. Hasil Pernyataan Responden Terhadap Variable ChangeIn Job Content (CJC)

\begin{tabular}{|l|l|l|l|l|l|l|}
\hline No & \multicolumn{1}{|c|}{ Pernyataan } & \multicolumn{1}{|c|}{ STS } & \multicolumn{1}{|c|}{ TS } & \multicolumn{1}{c|}{ BS } & \multicolumn{1}{c|}{ SS } \\
\hline 1 & $\begin{array}{l}\text { SIAKAD berbasis WEB online dapat menghambat } \\
\text { pekerjaan }\end{array}$ & 7 & 47 & 26 & 15 & 5 \\
\hline
\end{tabular}




\begin{tabular}{|l|l|l|l|l|l|l|}
\hline No & \multicolumn{1}{|c|}{ Pernyataan } & \multicolumn{1}{|c|}{ STS } & \multicolumn{1}{|c|}{ TS } & \multicolumn{1}{|c|}{ BS } & \multicolumn{1}{|c|}{ S } & \multicolumn{1}{|c|}{ SS } \\
\hline 2 & $\begin{array}{l}\text { Penerapan SIAKAD berbasis WEB online membuat } \\
\text { proses lebih cepat }\end{array}$ & - & 6 & 13 & 46 & 35 \\
\hline 3 & $\begin{array}{l}\text { User sering menduga -duga tentang cara penggunaan } \\
\text { SIAKAD berbasis WEB online dalam proses } \\
\text { akademik }\end{array}$ & - & 12 & 38 & 36 & 14 \\
\hline Jumlah (\%) variable Change In Job Content(CJC) & $\begin{array}{l}7 \\
(2 \%)\end{array}$ & $\begin{array}{l}65 \\
(22 \%)\end{array}$ & $\begin{array}{l}77 \\
(26 \%)\end{array}$ & $\begin{array}{l}97 \\
(32 \%)\end{array}$ & $\begin{array}{l}54 \\
(18 \%)\end{array}$ \\
\hline
\end{tabular}

Berdasarkan data tabel di atas didapatkan bahwa responden menyatakan SIAKAD berbasis online tidak menghambat pekerjaan, setuju bahwa SIAKAD berbasis WEB online membuat proses lebih cepat. Namun responden sering menduga-duga tentang cara penggunaan SIAKAD berbasis WEB online.

Tabel 3. Hasil Pernyataan Responden Terhadap Variabel Lack Of Communication Between Top Management \& End user (LCMU)

\begin{tabular}{|l|l|l|l|l|l|l|}
\hline No & \multicolumn{1}{|c|}{ Pernyataan } & \multicolumn{1}{|c|}{ STS } & \multicolumn{1}{|c|}{ TS } & \multicolumn{1}{|c|}{ BS } & \multicolumn{1}{|c|}{ S } & \multicolumn{1}{|c|}{ SS } \\
\hline 1 & $\begin{array}{l}\text { User mengikuti setiap proses perkembangan dari } \\
\text { SIAKAD berbasis WEB online }\end{array}$ & -26 & 50 & 21 \\
\hline 2 & $\begin{array}{l}\text { User memahami manfaat, perkembangan dan } \\
\text { pengoperasian ketika mengakses SIAKAD berbasis } \\
\text { WEB } \text { online }\end{array}$ & - & 2 & 26 & 53 & 17 \\
\hline 3 & $\begin{array}{l}\text { User memahami proses penggunaan dari SIAKAD } \\
\text { berbasis WEB online }\end{array}$ & - & 6 & 22 & 58 & 14 \\
\hline $\begin{array}{l}\text { Jumlah (\%) variable Lack of Communication Between } \\
\text { Top Management \& End User (LCMU) }\end{array}$ & $\begin{array}{l}0 \\
(0 \%)\end{array}$ & $\begin{array}{l}11 \\
(4 \%)\end{array}$ & $\begin{array}{l}76 \\
(25 \%)\end{array}$ & $\begin{array}{l}161 \\
(54 \%)\end{array}$ & $\begin{array}{l}52 \\
(17 \%)\end{array}$ \\
\hline
\end{tabular}

Berdasarkan data pada tabel di atas didapatkan bahwa lebih dari separuh responden setuju mengikuti setiap proses perkembangan dari SIAKAD berbasis WEB online, user memahami manfaat, perkembangan, dan pengoprasian ketika mengakses SIAKAD berbasis WEB online, user memahami proses penggunaan dari SIAKAD berbasis WEB online.

Tabel 4. Hasil Pernyataan Responden Terhadap Variabel Lack Of User Of Involvement In The Development Process (LUID)

\begin{tabular}{|c|c|c|c|c|c|c|}
\hline No & Pernyataan & STS & TS & BS & $\mathrm{S}$ & SS \\
\hline 1 & $\begin{array}{l}\text { User dapat mengakses SIAKAD berbasis WEB } \\
\text { online di dalam dan di luar lingkungan Universitas } \\
\text { PGRI Adi Buana Surabaya, dapat diakses oleh semua } \\
\text { dosen, karyawan dan staf }\end{array}$ & - & - & 10 & 46 & 44 \\
\hline 2 & $\begin{array}{l}\text { User dapat mengakses SIAKAD berbasis WEB } \\
\text { online dengan maksimal ketika berada di luar area } \\
\text { Universitas PGRI Adi Buana Surabaya }\end{array}$ & - & 7 & 10 & 48 & 35 \\
\hline \multirow[t]{2}{*}{3} & $\begin{array}{llr}\text { Fasilitas perangkat keras/hardware } & \text { yang } \\
\text { dipergunakan oleh user mempengaruhi } & \text { akses } \\
\text { SIAKAD berbasis WEB online } & \\
\end{array}$ & - & 11 & 27 & 45 & 17 \\
\hline & $\begin{array}{l}\text { Jumlah (\%) variable Lack Of User Involvement In The } \\
\text { Development Process (LUID) }\end{array}$ & $\begin{array}{l}0 \\
(0 \%)\end{array}$ & $\begin{array}{l}18 \\
(6 \%)\end{array}$ & $\begin{array}{l}47 \\
(16 \%)\end{array}$ & $\begin{array}{l}139 \\
(46 \%)\end{array}$ & $\begin{array}{l}96 \\
(32 \%)\end{array}$ \\
\hline
\end{tabular}

Berdasarkan tabel di atas dapat diketahui bahwa hampir setengah dari seluruh responden setuju SIAKAD berbasis online dapat diakses semua dosen, karyawan dan staf baik di dalam maupun di kampus. Akses maksimal ketika di luar area kampus dan penyediaan perangkat keras mempengaruhi akses SIAKAD berbasis WEB online.

Tabel 5. Hasil pernyataan Responden Terhadap Variabel Usability Issues \& Resistance To Technology (UIRT)

\begin{tabular}{|l|l|l|l|l|l|l|}
\hline No & \multicolumn{1}{|c|}{ Pernyataan STS } & TS & BS & S & SS \\
\hline 1 & $\begin{array}{l}\text { Kendala dalam pemanfaatan SIAKAD berbasis } \\
\text { WEB online adalah kemampuan teknologi setiap } \\
\text { user yang berbeda }\end{array}$ & 4 & 5 & 22 & 57 & 12 \\
\hline
\end{tabular}




\begin{tabular}{|c|c|c|c|c|c|c|}
\hline No & Pernyataan & STS & $\mathrm{TS}$ & $\mathrm{BS}$ & $\mathrm{S}$ & SS \\
\hline 2 & $\begin{array}{l}\text { User merasa terbantu dengan adanya SIAKAD } \\
\text { berbasis WEB online }\end{array}$ & - & 4 & 17 & 47 & 32 \\
\hline 3 & $\begin{array}{l}\text { Kecepatan jaringan data internet sangat mendukung } \\
\text { kecepatan data yang diakses pada SIAKAD berbasis } \\
\text { WEB online }\end{array}$ & 1 & 8 & 15 & 54 & 22 \\
\hline \multirow[t]{2}{*}{4} & $\begin{array}{l}\text { Software SIAKAD berbasis WEB online sangat } \\
\text { mendukung untuk mendapatkan informasi akademik }\end{array}$ & 1 & - & 24 & 50 & 25 \\
\hline & $\begin{array}{l}\text { Jumlah (\%) variable Usability Issues \& Resistance } \\
\text { To Technology (UIRT) }\end{array}$ & $\begin{array}{l}6 \\
(1,5 \%)\end{array}$ & $\begin{array}{l}17 \\
(4 \%)\end{array}$ & $\begin{array}{l}78 \\
(19,5 \%)\end{array}$ & $\begin{array}{l}208 \\
(52 \%)\end{array}$ & $\begin{array}{l}91 \\
(23 \%)\end{array}$ \\
\hline
\end{tabular}

Berdasarkan data pada tabel dapat diketahui bahwa lebih dari setengah dari seluruh responden setuju kendala dalam pemanfaatan SIAKAD berbasis online adalah kemampuan user yang berbeda, user terbantu dengan adanya SIAKAD berbasis online, kecepatan jaringan data internet mendukung kecepatan akses data dan software SIAKAD berbasis online sangat mendukung untuk mendapatkan informasi akademik.

Tabel 6. Hasil Pernyataan Responden Terhadap Variabel Increased Effort (IE)

\begin{tabular}{|c|c|c|c|c|c|c|}
\hline No & Pernyataan & STS & $\mathrm{TS}$ & $\mathrm{BS}$ & $S$ & SS \\
\hline 1 & $\begin{array}{l}\text { User sudah memanfaatkan setiap menu di dalam } \\
\text { SIAKAD berbasis online secara cepat }\end{array}$ & - & 6 & 30 & 43 & 21 \\
\hline 2 & $\begin{array}{l}\text { User memiliki fasilitas penunjang (hardware dan } \\
\text { jaringan) ketika mengakses SIAKAD berbasis WEB } \\
\text { online }\end{array}$ & 1 & 10 & 34 & 45 & 10 \\
\hline \multirow[t]{2}{*}{3} & $\begin{array}{l}\text { Kecepatan jaringan data internet sangat mendukung } \\
\text { kecepatan data yang diakses pada SIAKAD berbasis } \\
\text { WEB online }\end{array}$ & 3 & 7 & 33 & 45 & 12 \\
\hline & Jumlah (\%) variable Increased Effort (IE) & $\begin{array}{l}4 \\
(1.5 \%)\end{array}$ & $\begin{array}{l}23 \\
(8 \%)\end{array}$ & $\begin{array}{l}97 \\
(32 \%)\end{array}$ & $\begin{array}{l}133 \\
(44 \%)\end{array}$ & $\begin{array}{l}43 \\
(14.5 \%)\end{array}$ \\
\hline
\end{tabular}

Berdasarkan data pada tabel didapatkan bahwa hampir setengah dari responden menyatakan setuju. Dimana user sudah memanfaatkan setiap menu di dalam SIAKAD berbasis online secara cepat, user memiliki fasilitas penunjang ( hardware dan jaringan) ketika mengakses SIAKAD berbasis WEB online, kemudian kecepatan jaringan data internet sangat mendukung kecepatan data yang diakses pada SIAKAD berbasis WEB online.

Tabel 7. Hasil Pernyataan Responden Terhadap Variabel User Espectation (UE)

\begin{tabular}{|c|c|c|c|c|c|c|}
\hline No & Pernyataan & STS & TS & BS & $\mathrm{S}$ & SS \\
\hline 1 & $\begin{array}{l}\text { User dapat memperoleh manfaat dengan } \\
\text { menggunakan SIAKAD untuk informasi akademik } \\
\text { dan kegiatan akademik( misal KRS, KHS, dll) }\end{array}$ & 1 & 1 & 6 & 52 & 40 \\
\hline 2 & $\begin{array}{l}\text { SIAKAD berbasis WEB online dapat menghemat } \\
\text { waktu user dalam proses pelaksanaan informasi } \\
\text { akademik dan kegiatan akademik( misal KRS, KHS, } \\
\text { dll) }\end{array}$ & 1 & 5 & 14 & 50 & 31 \\
\hline \multirow[t]{2}{*}{3} & $\begin{array}{l}\text { User sudah memanfaatkan SIAKAD berbasis WEB } \\
\text { online untuk informasi dan kegiatan akademik ( } \\
\text { misal KRS, KHS, dll) }\end{array}$ & 2 & - & 13 & 50 & 35 \\
\hline & Jumlah (\%) variable User Espectation (UE & $\begin{array}{l}4 \\
(1.5 \%)\end{array}$ & $\begin{array}{l}6 \\
(2 \%)\end{array}$ & $\begin{array}{l}33 \\
(11 \%)\end{array}$ & $\begin{array}{l}152 \\
(50.5 \%)\end{array}$ & $\begin{array}{l}106 \\
(35 \%)\end{array}$ \\
\hline
\end{tabular}

Berdasarkan tabel didapatkan data bahwa setengah dari responden menyatakan setuju user dapat memperoleh manfaat dengan menggunakan SIAKAD untuk informasi akademik dan kegiatan akademik (misal KRS, KHS, dll). SIAKAD berbasis WEB online dapat menghemat waktu user dalam proses pelaksanaan informasi akademik dan kegiatan akademik (misal KRS, KHS, dll). User juga sudah memanfaatkan SIAKAD berbasis WEB online untuk informasi dan kegiatan akademik ( misal KRS, KHS, dll). 
- Analisis Deskriptif Variabel Resistance Due To Change (RDC)

Sebagaimana dijelaskan dalam devinisi Resistance Due To Change (RDC) yang merupakan salah satu variabel bebas dengan 4 pernyataan yang ditunjukkan pada tabel di bawah ini :

Tabel 8. Hasil Pernyataan Responden Terhadap Variabel Resistance Due To Change (RDC)

\begin{tabular}{|c|c|c|c|c|c|c|}
\hline No & Pernyataan & STS & TS & BS & S & SS \\
\hline 1 & $\begin{array}{l}\text { User memperoleh kesulitan dalam mengakses } \\
\text { setiap pilihan menu di SIAKAD berbasis WEB } \\
\text { online }\end{array}$ & 3 & 36 & 33 & 19 & 9 \\
\hline 2 & $\begin{array}{l}\text { SIAKAD berbasis WEB online belum berjalan } \\
\text { dengan maksimal (dalam sisi penggunaan oleh } \text { user) }\end{array}$ & - & 15 & 22 & 39 & 24 \\
\hline 3 & $\begin{array}{l}\text { Penyampaian mengenai perkembangan dan cara } \\
\text { penggunaan SIAKAD berbasis WEB online belum } \\
\text { maksimal }\end{array}$ & 1 & 11 & 22 & 55 & 11 \\
\hline 4 & $\begin{array}{l}\text { Kecepatan jaringan data internet mempengaruhi } \\
\text { akses penggunaan SIAKAD berbasis WEB online }\end{array}$ & - & 11 & 18 & 45 & 26 \\
\hline & $\begin{array}{l}\text { Jumlah (\%) variable( Resistance Due To Change } \\
(R D C)\end{array}$ & $\begin{array}{l}4 \\
(1 \%)\end{array}$ & $\begin{array}{l}73 \\
(18 \%)\end{array}$ & $\begin{array}{l}95 \\
(24 \%)\end{array}$ & $\begin{array}{l}158 \\
(39.5 \%)\end{array}$ & $\begin{array}{l}70 \\
(17,5 \%)\end{array}$ \\
\hline
\end{tabular}

Berdasarkan tabel dapat diketahui bahwa sepertiga responden menyatakan tidak setuju bila user memperoleh kesulitan dalam mengakses setiap pilihan menu di SIAKAD berbasis WEB online, lebih dari sepertiga responden menyatakan setuju SIAKAD berbasis WEB online belum berjalan dengan maksimal (dari sisi penggunaan oleh user). Penyampaian mengenai perkembangan dan cara penggunaan SIAKAD berbasis WEB online belum maksimal, kecepatan jaringan data internet mempengaruhi akses penggunaan SIAKAD berbasis WEB online.

Tabel 9. Distribusi Frekwensi variabel Resistansi Pengguna dalam penggunaan SIAKAD di Universitas PGRI Adi Buana Surabaya

\begin{tabular}{|c|c|c|c|c|c|c|}
\hline $\mathrm{NO}$ & Variabel & STS & TS & $\mathrm{BS}$ & $\mathrm{S}$ & SS \\
\hline 1 & Lack of User Education \& Training(LUET) & $\begin{array}{l}0 \\
(0 \%)\end{array}$ & $\begin{array}{l}36 \\
(12 \%)\end{array}$ & $\begin{array}{l}66 \\
(22 \%)\end{array}$ & $\begin{array}{l}151 \\
(50 \%)\end{array}$ & $\begin{array}{l}47 \\
(16 \%)\end{array}$ \\
\hline 2 & Change In Job Content (CJC) & $\begin{array}{l}7 \\
(2 \%)\end{array}$ & $\begin{array}{l}65 \\
(22 \%)\end{array}$ & $\begin{array}{l}77 \\
(26 \%)\end{array}$ & $\begin{array}{l}97 \\
(32 \%)\end{array}$ & $\begin{array}{l}54 \\
(18 \%)\end{array}$ \\
\hline 3 & $\begin{array}{l}\text { Lack of Communication Between Top } \\
\text { Management \& End User (LCMU) }\end{array}$ & $\begin{array}{l}0 \\
(0 \%)\end{array}$ & $\begin{array}{l}11 \\
(4 \%)\end{array}$ & $\begin{array}{l}76 \\
(25 \%)\end{array}$ & $\begin{array}{l}161 \\
(54 \%)\end{array}$ & $\begin{array}{l}52 \\
(17 \%)\end{array}$ \\
\hline 4 & $\begin{array}{l}\text { Lack Of User Involvement In The } \\
\text { Development Process (LUID) }\end{array}$ & $\begin{array}{l}0 \\
(0 \%)\end{array}$ & $\begin{array}{l}18 \\
(6 \%)\end{array}$ & $\begin{array}{l}47 \\
(16 \%)\end{array}$ & $\begin{array}{l}139 \\
(46 \%)\end{array}$ & $\begin{array}{l}96 \\
(32 \%)\end{array}$ \\
\hline 5 & $\begin{array}{l}\text { Usability Issues \& Resistance To Technology } \\
\text { (UIRT) }\end{array}$ & $\begin{array}{l}6 \\
(1,5 \%)\end{array}$ & $\begin{array}{l}17 \\
(4 \%)\end{array}$ & $\begin{array}{l}78 \\
(19,5 \%)\end{array}$ & $\begin{array}{l}208 \\
(52 \%)\end{array}$ & $\begin{array}{l}91 \\
(23 \%)\end{array}$ \\
\hline 6 & Increased Effort (IE) & $\begin{array}{l}4 \\
(1.5 \%)\end{array}$ & $\begin{array}{l}23 \\
(8 \%)\end{array}$ & $\begin{array}{l}97 \\
(32 \%)\end{array}$ & $\begin{array}{l}133 \\
(44 \%)\end{array}$ & $\begin{array}{l}43 \\
(14.5 \%)\end{array}$ \\
\hline 7 & User Espectation (UE) & $\begin{array}{l}4 \\
(1.5 \%)\end{array}$ & $\begin{array}{l}6 \\
(2 \%)\end{array}$ & $\begin{array}{l}33 \\
(11 \%)\end{array}$ & $\begin{array}{l}152 \\
(50.5 \%)\end{array}$ & $\begin{array}{l}106 \\
(35 \%)\end{array}$ \\
\hline 8 & Resistance Due To Change (RDC) & $\begin{array}{l}4 \\
(1 \%)\end{array}$ & $\begin{array}{l}73 \\
(18 \%)\end{array}$ & $\begin{array}{l}95 \\
(24 \%)\end{array}$ & $\begin{array}{l}158 \\
(39.5 \%)\end{array}$ & $\begin{array}{l}70 \\
(17,5 \%)\end{array}$ \\
\hline
\end{tabular}

Berdasarkan data pada tabel dapat diketahui bahwa faktor yang mempengaruhi resistansi pengguna dalam penggunaan SIAKAD di Universitas PGRI Adi Buana Surabaya berturut-turut adalah variabel komunikasi antara pimpinan dengan pengguna (54\%), Usability Issues \& Resistance To Technology $=U I R T(52 \%)$, User Espectation $=U E(50,5 \%)$, dan Lack of User Education \& Training =LUET( 50\%)

\section{PEMBAHASAN}

- Pengaruh kurangnya pendidikan dan pelatihan pengguna dalam implementasi SIAKAD

Berdasarkan data pada tabel 5.1 didapatkan bahwa $50 \%$ responden menyatakan setuju perlu pelatihan tentang penggunaan SIAKAD 
berbasis WEB Online, responden sudah mendapatkan informasi dan sosialisasi tentang penggunaan SIAKAD berbasis WEB Online.

Kurangnya pengalaman pendidikan dan pelatihan dari pengguna akan berdampak pada masalah penggunaan dan resistansi terhadap teknologi secara umum. Kondisi ini senada dengan laporan Salih, et al. (2010) yang menunjukkan adanya korelasi kuat antara LEUT dan UIRT dengan koefisien korelasi0,87. Pembuktian hipotesis tersebut menunjukkan bahwa pendidikan dan pelatihan bagi pengguna mutlak diperlukan mengiringi implementasi sistem informasi. Hal ini diharapkan dapat memberikan jaminan agar pengguna sistem menjadi lebih familier terhadap teknologi, sehingga dapat mengurangi perilaku resistan terhadap teknologi tersebut. Upaya ini penting dilakukan, mengingat bahwa setiap perubahan (termasuk implementasi SIAKAD) pasti akan mendapatkan perlawanan dari homeostasis dari masing-masing individu pengguna (Gunawan, 2007). Untuk mencapai Sistem Informasi Akademik yang berjalan efektif, mampu membantu stakeholder internal ataupun eksternal dengan menyediakan informasi yang akurat, cepat, dan cukup maka diperlukan Sumber Daya Manusia (SDM) yang handal. SDM sistem informasi akademik yang handal ditentukan oleh beberapa faktor yaitu budaya TIK positif yang berkembang pada konteks SIAKAD itu berada (lingkungan perguruan tinggi), pendidikan dan pelatihan SDM, sistem reward, dan standar kompetensi personel SIAKAD.

Mengacu pada defenisi budaya TIK yang digambarkan oleh Slamet dan kawankawan(2008:51), budaya TIK yang positif bisa dilukiskan dengan suatu keadaan dimana warga perguruan tinggi menganut nilai-nilai, kebiasaan, yang menggambarkan mereka melek dan sadar akan TIK. Mereka tahu fungsi, makna, dan filosofi dari TIK dan mampu mengadaptasikannya dengan keseharian mereka. Selain itu, suasana kerja di perguruan tinggi menggambarkan dimana komponen perguruan tinggi tersebut (orang, tugas, proses interaksi, perilaku organisasi) terikat dan familiar dengan TIK. Jika budaya TIK sudah positif berkembang di lingkungan perguruan tinggi, tentu ini akan menjadi atmosfer segar bagi sistem informasi akademik khususnya, informasi manajemen pada umumnya bisa berjalan dengan efektif.

Pendidikan dan pelatihan merupakan syarat penting penciptaan SDM yang kompeten. Pendidikan dan pelatihan tidak hanya membekali wawasan keilmuan dan keterampilan yang terkait dengan operasionalisasi manajemen sistem informasi akademik, tetapi juga menanamkan nilainilai profesional profesi pengelola sistem informasi akademik. Dengan pendidikan dan pelatihan, tidak hanya memberikan ilmu baru, tetapi juga memberikan penyegaran tentang kompetensi yang dimiliki personalia sistem informasi akademik.

Pendidikan dan pelatihan ini merupakan investasi jangka panjang bagi keberlangsungan sistem informasi akademik perguruan tinggi. Sistem reward dimaksudkan sebagai mekanisme pendorong bagi para personel untuk lebih bergairah dalam bekerja, memiliki etos kerja yang tinggi, bertanggung jawab, dan tentu sejahtera. Sistem reward tidak hanya berupa sistem imbalan materi saja, tetapi juga sistem promosi atau demosi jenjang karir. Hal tersebut bisa memperbaiki suasana psikologis para personel sistem informasi akademik. Turn over dan brain drain merupakan salah satu target dari dari sistem reward ini. Selama ini, profesi IT merupakan profesi yang masih cukup langka. Salah satu strategi yang cukup mampu mempertahankan para tenaga terlatih ini tetap tinggal di lembaga adalah dengan sistem reward tersebut.

Standar kompetensi merupakan hal penting terkait dengan profesionalisme SDM sistem informasi akademik. Standar kompetensi merupakan pernyataan-pernyataan mengenai pelaksanaan tugastugas di tempat kerja yang berisikan hal-hal yang diharapkan bisa dilaksanakan oleh para petugas sistem informasi akademik. Tidak hanya itu, standar kompetensi ini juga memuat tentang deskripsi tingkat kesempurnaan pelaksanaan kerja yang diharapkan dari para petugas SIAKAD. Selain itu, standar kompetensi juga bisa dijadikan pedoman penilaian kemampuan personel. Tambahannya, Standar kompetensi profesi SIAKAD berguna untuk efisiensi dan membuat pendidikan dan pelatihan keterampilan SIAKAD menjadi lebih relevan.

Seperti diutarakan Sutermeister (1976:45) bahwa keberadaan teknologi penting bagi pencapaian tugas-tugas organisasi, keberadaan parangkat TIK dalam pengelolaan sistem informasi akademik cukup penting. Kemampuan bekerja yang cepat, bisa memproses data dengan banyak dan bisa bekerja 24 jam menjadi salah satu keunggulan sarana TIK ini. Kecanggihan atau kemutakhiran gadget TIK bukan jaminan pengerjaan pekerjaan-pekerjaan SIAKAD akan efektif.

Pemilihan hardware dan software yang tepat adalah kuncinya. Selain itu, cara pemeliharaan dan penanganan sistem keamanan juga harus diperhatikan agar keberlangsungan pemanfaatan sarana TIK bisa lebih lama. Peran data base sebagai penampung dan mendistribusikan data yang akan dan telah diolah menjadi informasi sangat penting sekali. Ia akan secara simultan bekerja melayani semua pihak yang berkepentingan dengan informasi akademik. Data base yang baik adalah date base yang manajemen basis datanya mendukung proses pembuatan keputusan. Dalam proses pelayanan, pengguna yang mengakses sistem informasi akademik akan senantiasa disokong oleh aliranaliran data dan informasi yang berasal dari data 
base. Selain itu, input-input yang mereka masukan ke sistem informasi akademik juga akan tersimpan di data base. Bagi lembaga, data base diibaratkan sebagai gudang penyimpanan harta yang sangat berharga. Gudang itu harus benar sistem manajemen inventorinya, sistem keamanannya, dan tentunya penataan barang-barang (data) yang akan disimpan di dalamnya.

Data base ini dengan melalui bantuan teknologi disuplai dari berbagai sumber pengguna. Ia memuat tentang data kemahasiswaan, akademik, ketenagaan, keuangan, dan data pendukung lainnya. Secara bersama-sama ia akan digunakan oleh berbagai modul aplikasi manajemen sistem informasi yang diaplikasikan lembaga. Dengan interface dan integrator teknologi proses input dan komunikasi data/informasi berjalan bolak balik dari sumber ke server diolah dan disebarkan kembali ke pengguna. Input data berupa profil diri mahasiswa, profil akademiknya, beban tugas mengajar dosen, jadwal kuliah, atau yang lainnya diinputkan kedalam database yang terinstal di server, kemudian dengan sistem diolah menjadi berbagai macam informasi dan pengetahuan, misalnya menjadi kartu hasil studi, rencana studi, pembagian penjadwalan ruangan kelas, ringkasan beban mengajar dosen, atau yang lainnya.

\section{- Pengaruh perubahan beban kerja pengguna dalam implementasi SIAKAD}

Berdasarkan data Tabel 2 dapat diketahui bahwa responden menyatakan SIAKAD berbasis online tidak menghambat pekerjaan. Responden juga setuju bahwa SIAKAD berbasis WEB online membuat proses lebih cepat. Namun responden masih sering menduga-duga tentang cara penggunaan SIAKAD berbasis WEB online. Ini menunjukkan bahwa perubahan isi pekerjaan (dalam hal ini adalah perubahan dari offline system menuju online system) telah berdampak pada masalah penggunaan dan resistansi terhadap teknologi. Pembuktian hipotesis ini relevan dengan hasil penelitian Salih, et al. (2010) yang membuktikan kuatnya hubungan antara CJC dan UIRT dengan koefisien korelasi 0,85. Ini mengindikasikan bahwa perubahan job content sebagai akibat dari implementasi sistem informasi harus mendapatkan perhatian khusus. Pada umumnya para calon pengguna sistem telah berada dalam comfort zone (zona yang nyaman) dalam keadaan status quo, sehingga setiap perubahan (khususnya perubahan yang bersifat radikal) akan menimbulkan gangguan terhadap homeostasis atau ekuilibrium ini (Gunawan, 2007).

melibatkan para pengguna dalam proses perubahan menuju implementasi sistem baru berbasis teknologi, maka secara bertahap mereka

\section{- Pengaruh kurangnya komunikasi antara pimpinan dengan pengguna dalam implementasi SIAKAD}

Berdasarkan data pada Tabel 3 dapat diketahui bahwa lebih dari separuh responden setuju mengikuti setiap proses perkembangan dari SIAKAD berbasis WEB online. Responden sepakat bahwa user memahami manfaat, perkembangan, dan pengoperasian ketika mengakses SIAKAD berbasis WEB online, user memahami proses penggunaan dari SIAKAD berbasis WEB online. Dengan demikian kurangnya komunikasi antara pimpinan institusi dengan pengguna SIAKAD tidak berpengaruh terhadap harapan pengguna terkait SIAKAD. Berarti, dalam lingkup penerapan SIAKAD setempat, harapan berpengaruh sangat kuat terhadap UE dengan koefisien korelasi sebesar 0,97. LCMU adalah variabel yang tidak mempengaruhi terjadinya resistansi pengguna SIAKAD di Universitas PGRI Adi Buana Surabaya. Pengguna tidak dipengaruhi oleh komunikasi antara pimpinan institusi dan pengguna.

\section{- Pengaruh kurangnya terlibatnya pengguna dalam proses pengembangan sistem dalam implementasi SIAKAD}

Berdasarkan Tabel 4 dapat diketahui bahwa hampir setengah dari seluruh responden setuju SIAKAD berbasis online dapat diakses semua dosen, karyawan dan staf baik di dalam maupun di kampus. Akses maksimal ketika di luar area kampus dan penyediaan perangkat keras mempengaruhi akses SIAKAD berbasis WEB online.

Kurangnya keterlibatan pengguna dalam pengembangan SIAKAD akan berdampak pada harapan pengguna. Kondisi ini senada dengan hasil penelitian Salih, et al. (2010) yang menunjukkan adanya korelasi yang sangat kuat antara LUID dan UE dengan koefisien korelasi 0,98. Ini menunjukkan bahwa keterlibatan pengguna dalam pengembangan sistem informasi mutlak diperlukan mengiringi implementasi sistem informasi. Jika pengguna dilibatkan dalam pengembangan sistem informasi, maka keinginan-keinginan para pengguna terkait dengan sistem tersebut dapat diakomodir secara dini. Dengan demikian dapat terbentuk sistem yang lebih familier bagi pengguna, baik terkait interface (tampilan), menu, variabel, serta fitur-fitur lainnya.

Jika sejak awal mereka telah terlibat di dalam pengembangan sistem, maka ketika sistem diimplementasikan tentu sudah banyak harapan yang terpuaskan, karena sudah diakomodir sejak sistem tersebut mulai dibangun. Upaya melibatkan pengguna dalam pengembangan sistem juga dapat meluruskan pemahaman yang keliru bahwa perubahan menuju hal yang baru merupakan langkah yang salah. Dengan

akan terpapar dengan teknologi yang akan diimplementasikan sehingga menjadi semakin familier terhadap teknologi tersebut. Ini merupakan 
salah satu bentuk dari educative change strategy dan rational/self-interest change strategy sebagaimana disampaikan oleh David (2001) dalam

\section{E. KESIMPULAN DAN SARAN}

\section{- Kesimpulan}

Dalam konteks implementasi SIAKAD berbasis web online, disimpulkan bahwa resistansi pengguna ditentukan oleh dua determinan langsung yaitu increased effort dan userexpectation dan empat determinan tak langsung yaitu lack of education and user training, change injob content, usability issues and resistance totechnology, dan lack of user involvement in thedevelopment process.

\section{F. DAFTAR PUSTAKA}

Ablett, E., Bellizzi, D., Byers, J., Cove, S.,Dobrusin, M., Frey, A. \& Hanke, J., 2013. Introduction of IS Management, San Fransisco:Wikispaces.

Cerom, M. R., \& Cregor, H. E. 2010. AvoidingManagement of Resistance During IT PreImplementation Phase: A LongitudinalResearch A High Tech Corporation.

David, F. R., 2001. Concepts of StrategicManagement. s.1.: Prentice Hall, Inc.

Davis, F. D., 1989. Perceived Usefulness,

PerceivedEase of Use, and User Acceptance of Information Technology. MIS Quarterly, XIII:319-339.

Davis, F. D., 1993. User Acceptance of InformationTechnology: System Characteristics, UserPerceptions and Behavioral Impacts.International Journal of Man-Machine Studies,XXXVIII: 475-487.

Gunawan, A.W., 2007. The Secret of Mainset.Jakarta: Gramedia Pustaka Utama. pembahasannya mengenai pendekatan-pendekatan dalam upaya mengatasi resistansi terhadap perubahan.

- Saran

1. Perlu pelatihan, informasi dan sosialisasi bagi pengguna tentang penggunaan SIAKAD berbasis WEB Online.

2. Perlu dibuat panduan tentang tata cara-cara penggunaan SIAKAD berbasis WEB online.

3. Komunikasi yang sudah terbangun baik antara pimpinan dengan pengguna SIAKAD berbasis WEB online perlu dipertahankan.

4. Perlu melibatkan pengguna dalam pengembangan SIAKAD berbasis WEB online.

Kazi, A.S., Aouad, C. \& Baldwin, A. 2009. AProcess View On End User Resistance During

Construction It Implementations. Journal ofInformation Technology in Construction, XIV:353-365.

Slamet, Razak Abdul, Deraman A. 2008. Mengeliminasi Resistensi Masa menuju Berbudaya ICTpada Organisasi Publik Pendekatan Kurt Lewin. Dalam Makalah-makalah Informatika

SistemInformasi. Bandung: Penerbit Sutabri, T., 2012. Konsep Sistem Informasi.Yogyakarta: Penerbit Andi.

Sutermeister, Robert A. (1976). People and Productivity. New York : Mc Graw Hill. Book Company

Wijaya, S. W. (2006). Kajian Teoritis TechnologyAcceptance Model sebagai Model Pendekatan untuk Menentukan Strategi Mendorong Kemauan Pengguna dalam Menggunakan Teknologi Informasi dan Komunikasi. Sistem Informasi dalam Berbagai Perspektif,I:186-189 